\title{
Integration or Separation: A Preface
}

\section{Donald Farren}

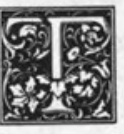

he Rare Books and Manuscripts Section of ACRL responds to the needs and concerns of librarians and specialists responsible for the care, custody, and use of rare books, manuscripts, and archives. The section also provides means by which librarians and specialists engaged in such work can communicate with others in the library world and beyond. The work of the section is carried out by twenty standing and ad hoc committees, which provide continuing education and which regularly produce standards and guidelines applicable to rare books and special collections work. The section has recently begun issuing a newsletter.

A major effort of the Rare Books and Manuscripts Section is its annual conference, which is scheduled just prior to the ALA Annual Conference and is located close to it. These conferences are intended to serve closely the current interests of the members of the section. For instance, in 1983 in Los Angeles the conference was held on the theme "The Enemies of Books Revisited," that is, on the conditions that limit the effectiveness of the work of rare book and special collections librarians. In 1984 in Austin the conference was held on the theme "Collecting the Twentieth Century."

At the Annual Conferences of the American Library Association, the Rare Books and Manuscripts Section cosponsors programs with such ALA units as the Preservation of Library Materials Section of the Resources and Technical Services Division, the Map and Geography Round Table, and the Library History Round Table; the section also offers its own general pro- gram meeting. The general program meetings of the Rare Books and Manuscripts Section are intended to appeal to a broad range of library interests, offering views from the perspective of rare books and special collections work. At the $1984 \mathrm{Dal}-$ las Annual Conference, for instance, the Rare Books and Manuscripts Section general program meeting was held on the theme "What Do I Do with My Rare Books?: Answers for the Librarian and the Patron."

The three papers that follow represent remarks made in a panel discussion that constituted the Rare Books and Manuscripts Section general program meeting at the 1983 ALA Annual Conference in Los Angeles. The theme of that meeting was "Manuscripts and Archives/ Rare Books and Other Printed Material: Integration or Separation?" The issue dealt with by the panelists was whether manuscripts and archival materials are better separated from or integrated with rare books and printed material in special collections. Three thoughtful practitioners offered different perspectives on the issue: Clifton $\mathrm{H}$. Jones, who is director of the DeGolyer Library of Southern Methodist University, Dallas; William L. Joyce, who is assistant director for Rare Books and Manuscripts at the New York Public Library; and Richard C. Berner, who was head of the University Archives \& Manuscripts Division in the University of Washington Libraries, Seattle, a post from which he is now retired.

Jones was responsible for describing and evaluating the separate traditions, conventions, patterns of training and experience, and peer group identification of 
archivists, manuscripts librarians, and librarians dealing with rare books and other printed materials. Joyce was responsible for describing and evaluating the administration of manuscripts and archives integrated with rare books and other printed material. Berner was responsible for describing and evaluating the administration of manuscripts and archives separate from rare books and other printed material. Quite naturally, the panelists' remarks ranged beyond the strict limits of the topics assigned them, both in their initial presentations and in the general discussion during the question-and-answer period.

There are no fixed solutions to the issues dealt with in these papers. In fact, some aspects of the same issues were taken up again in a panel discussion held during the 1984 annual meeting of the Society of American Archivists in Washington. The panel discussion on the theme "The Challenge of Integration: Promoting Special Collections in the Parent Institution" was organized by the Manuscript Repositories Section of the Society of American Archivists, which invited Washington-area members of the Rare Books and Manuscripts Section to participate.

These three papers reflect the thinking of the panelists at the time they delivered their remarks. By now their thinking has advanced by reason of further contemplation, consultation, and experience. It is hoped that readers of these papers will likewise be inspired to continue and to advance their thinking on the issues presented. 